\title{
Distribution review, habitat suitability and conservation of the endan- gered and endemic Moroccan spadefoot toad (Pelobates varaldii)
}

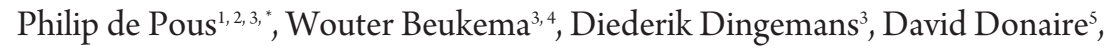 \\ Philippe Geniez ${ }^{6}$, El Hassan El Mouden \\ ${ }^{1}$ Escola Tècnica Superior d'Enginyeria Agrària, Departament de Producció Animal (Fauna Silvestre), University of Lleida, Lleida, Spain.
${ }^{2}$ Institute of Evolutionary Biology (CSIC-UPF), Barcelona, Spain.
${ }^{3}$ Society for the Preservation of Herpetological Diversity, Den Haag, the Netherlands.
${ }^{4}$ ITC, Faculty of Geo-Information Science and Earth Observation, University of Twente, Enschede, the Netherlands.
${ }^{5}$ Calle Mar Egeo 7, 11407 Jerez de la Frontera, Cádiz, Spain.
${ }^{6}$ Biogéographie et Ecologie des Vertébrés, Ecole Pratique des Hautes Etudes, UMR 5175, CEFE-CNRS, Montpellier, France.
7 Université Cadi Ayyad, Faculté des Sciences Semlalia, Laboratoire Biodiversité et Dynamique des Ecosystèmes, Marrakech, Morocco.
${ }^{*}$ Correspondence: Escola Tècnica Superior d'Enginyeria Agrària, Departament de Producció Animal (Fauna Silvestre), University of
Lleida, Lleida, Spain. E-mail: philipdepous@gmail.com
}

Received: 12 August 2011; received in revised form: 21 February 2012; accepted: 23 April 2012.

The Moroccan spadefoot toad (Pelobates varaldii) has received little scientific attention since its discovery. Currently, $P$. varaldii is listed as Endangered on the IUCN Red List due to a multitude of threats, while its distribution is partially unknown and fragmented. The current study addresses distribution, threats and the potential niche using ecological niche modelling, while emphasizing conservation strategies and immediate actions. The distribution of $P$. varaldii can be divided into four disjunct areas, at least two of which consist of small populations. The largest threats to $P$. varaldii include the transformation of habitat and breeding ponds into agricultural and industrial areas, the pollution of breeding ponds due to extensive livestock pasturing and the possible expansion of Procambarus sp. into the Mamora cork oak forest. Additional threats constitute a reduction of gene flow and loss of genetic variability as a result of habitat fragmentation. The ecological niche models (ENMs) of $P$. varaldii revealed fundamental environmental conditions along parts of the northeast Moroccan Atlantic and Mediterranean coastline. The species mainly inhabits well vegetated areas upon Quaternary soils at low altitudes. Proposed conservation actions include the development of a biannual monitoring program, identification and designation of protected areas within the distribution and development of a management plan for Mamora forest.

Key words: Anura; conservation; habitat suitability; Maxent; Morocco; NDVI.

Revisión de la distribución, idoneidad del hábitat y conservación del amenazado endemismo sapo de espuelas marroquí (Pelobates varaldii). Desde su descubrimiento, el sapo de espuelas marroquí (Pelobates varaldii) ha recibido poca atención por parte de la comunidad científica. Como consecuencia de multitud de amenazas, $P$. varaldii está actualmente catalogado como En Peligro de Extinción en la lista roja de la UICN, siendo su distribución muy fragmentada y no completamente conocida. El presente estudio analiza su distribución, amenazas y nicho potencial utilizando el modelado de nicho ecológico al tiempo que se enfatiza en posibles estrategias de conservación y acciones inmediatas. La distribución de $P$. varaldii puede dividirse en cuatro áreas disyuntas, al menos dos de las cuales corresponden a poblaciones de pequeño tamaño. Las mayores amenazas para $P$. varaldii incluyen la transformación de su hábitat y medios de reproducción en áreas agrícolas e industriales, la contaminación de sus charcas de reproducción como consecuencia de la ganadería extensiva y la posible expansión de Procambarus sp. hacia el alcornocal de Mamora. La reducción del flujo genético y pérdida de variabilidad genética como consecuencia de la fragmentación del hábitat constituyen amenazas adi- 
cionales. Los Modelos de Nicho Ecológico (ENMs) de P. varaldii revelaron determinadas condiciones ambientales fundamentales a lo largo de algunos sectores de las costas atlántica y mediterránea del nordeste de Marruecos. La especie habita principalmente en áreas con vegetación ubicadas sobre sustratos cuaternarios a baja altitud. Las acciones de conservación propuestas incluyen el desarrollo de un programa de seguimiento bianual, la identificación y designación de áreas protegidas dentro del rango de distribución y el desarrollo de un plan de gestión del alcornocal de Mamora.

Key words: Anura; conservación; idoneidad del hábitat; Maxent; Marruecos; NDVI.

The Moroccan spadefoot toad (Pelobates varaldii) was first mentioned in the literature by PELLEGRIN (1925) under the denomination Pelobates cultripes (Cuvier, 1829) before it was described as a separate species by PASTEUR \& BONS (1959), based on morphological and osteological characters. Subsequently, the species received little scientific attention until BUSACK et al. (1985) confirmed differentiation between $P$. varaldii and $P$. cultripes based on electrophoretical and immunological analyses, and suggested the species to have diverged since the Early Pliocene. In recent years, GARCÍA-PARÍs et al. (2003) and VEITH et al. (2006) found a wellsupported sister taxon relationship between $P$. varaldii and $P$. cultripes, which, according to their results, likely diverged after the collapse of the Gibraltar land bridge during the end of the Messinian salinity crisis, approximately 5.3 millions of years ago (KRIJGMAN et al., 1999).

The distribution of $P$. varaldii was long considered to be confined to a rectangle delimited by the towns Mehdia, Sidi Slimane, Khemisset and Rabat, until DORDA DORDA (1984) recorded the species $20 \mathrm{~km}$ south of Larache, thus expanding the range of the species about 70 $\mathrm{km}$ northwards. A few years later, DESTRE et al. (1989) significantly increased the range of the species southwards to Bir Jdid, the mouth of the Oued Nefifikh and Oualidia, as well as northwards into the town of Larache. BONS \& GENIEZ (1996) provided an overview of all the known localities up to that point and provided the first detailed distribution map (51 unique localities). The confirmation of the species near Oualidia, with the finding of live specimens in 2001 by Crochet \& Geniez (2003) and in 2007 (J.M. Thirion, A. Portheault, P. Evrard, personal communication) not only confirmed the records of DESTRE et al. (1989), but also definitely increased the range of $P$. varaldii 190 $\mathrm{km}$ southwards. More recently, GUZMÁN et al. (2007) expanded the range of the species several kilometres eastwards with records just south of Ouezzane, while LAPEÑA et al. (2011) reported the species between Asilah and Tangier, extending the distribution around $50 \mathrm{~km}$ northwards.

Despite these recent range extensions, $P$. varaldii is currently listed as Endangered (B2ab(iii)) on the IUCN Red List because its area of occupancy is probably less than $500 \mathrm{~km}^{2}$, the distribution is severely fragmented, and there is a continuing decline in the extent and quality of its habitat in Morocco (SALVADOR et al., 2004; Pleguezuelos et al., 2010). Additionally, the species does not occur in any protected area (DE POUS et al., 2011). The main threats to $P$. varaldii include the transformation of habitat and breeding ponds into agricultural and industrial areas, intensification of livestock pasturing, including the pollution of stagnant waters with livestock droppings (e.g. KNUTSON et al., 2004), while arable agriculture may be lea- 
ding to the loss or disturbance of the sandy substrate, which the species is strongly associated with. Populations of $P$. varaldii are now often restricted to the direct vicinity of temporary ponds, and those remaining in permanent water bodies are being eliminated through the presence of the predatory mosquito fish Gambusia holbrooki (SALVADOR et al., 2004; authors' personal observation). The Evolutionary Distinctive and Globally Endangered (EDGE) program of the Zoological Society of London recently listed $P$. varaldii on place 36 of their EDGE global amphibian top 100 (ISAAC et al., 2007), making a review of the species distribution, conservation status and range wide threats highly preferred.

In this paper we aim at: (1) reviewing the complete distribution of $P$. varaldii, (2) identifying threats, (3) analysing habitat suitability and (4) emphasizing conservation strategies.

\section{MATERIALS AND METHODS}

\section{Species occurrence records}

From December 2008 until April 2009 and from January until the end of February 2010, the entire distribution range of $P$. varaldii was visited to collect data on distribution and threats. Suitable areas characterized by presence of temporary ponds were selected with the use of satellite images (Google Earth ${ }^{\circ}$ ), preliminary ecological niche models (ENMs) and maps of the area (1:50 000). Larvae were sampled by standardized dip netting of temporary ponds using a $55 \times 70 \mathrm{~cm}$ dip net with a mesh width of $3 \mathrm{~mm}$. Dip netting is a standard technique used to sample amphibian assemblages in lentic habitats (SHAFFER et al., 1994) and sampling of larvae is in the case of such a rare, nocturnal and fossorial species more appropriate.
Additionally, adults were searched for during night time surveys (visual encounter surveys and road surveys). GPS coordinates (WGS 1984) of each locality were taken and descriptions of habitat, possible threats and population status were noted.

A total of 220 distribution records were assembled from literature and fieldwork. The distribution records went through a process of filtering such as removing duplicate records within unique grid cells in ENMtools 1.3 (WARREN et al., 2010) and thinning of dense clusters using a kernel density grid as implemented in the Java program OccurrenceThinner v.1.0.2 (VERBRUGGEN, 2012). After filtering, a total of 43 distribution records were used for ENM. Most of these records $(\mathrm{N}=41)$ were collected in the field using GPS devices while additional records $(\mathrm{N}=2)$ were derived from GUZMÁN et al. (2007) and LAPEÑA et al. (2011).

\section{Ecological niche modelling}

Initially, a total of 19 BioClim variables and altitude were downloaded from the WorldClim database version 1.4 (HiJMANs et al., 2005a) to form the climatic dataset (HijMANs et al., 2005b) at a resolution of 30 arc seconds (nearly $1 \times 1 \mathrm{~km}$ ). Additionally, a categorical normalized difference vegetation index (NDVI) and superficial geology were obtained from BEUKEMA et al. (2010) and downloaded from PERSITs et al. (1997), respectively. Collinearity of the variables was measured with Pearson's correlation coefficient in ENMtools 1.3. A total of 11 variables, all of which had a correlation degree lower than 0.75 (Pearson coefficient) were retained. Selection of predictor variables was 
based on ecological understanding of the species (e.g. rainfall in the breeding season).

The models were generated by the presence/background algorithm Maxent, version 3.3.3k (Phillips et al., 2006; Phillips \& DudíK, 2008). It has been shown that Maxent produces high quality predictions that are often more successful when evaluated and compared with other predictive models (HERNANDEZ et al., 2006; JimÉNEZ-VALVERDE et al., 2008; GiovANELLI et al., 2010). Additionally, Maxent has a successful prediction power even when using low sample sizes (PEARSON et al., 2007; WISZ et al., 2008). This algorithm uses environmental parameters in combination with geographical coordinates in order to predict the distribution of the species of interest. Maximum entropy is achieved by the constraint that the expected value for each variable under the estimated distribution has to match its empirical average - the mean value of a random set of coordinates within the distribution (PHILLIPS et al., 2006) -. In other words, the model minimi-

Figure 1: Overview map of the Kingdom of Morocco with an identification of altitude (darker colours indicating higher altitude) and the main topographic and geographic features. zes the relative entropy between two probability densities (one from the presence data and one from the landscape) defined in covariate space (EurTH et al., 2010). The model output displays the relative occurrence probability of a species within the grid cells of the study area. Maxent was used with default settings (Convergence threshold $=0.00001$, maximum number of iterations $=500$ and $\beta_{j}=1$ ) while partitioning the geographical records between training and test samples ( $75 \%$ and $25 \%$ respectively). This technique has been proven to achieve high predictive accuracy (PHILLIPS \& Dudík, 2008).

Several studies have recently addressed the importance of selecting pseudo-absence or background locations in ENM (e.g. VANDERWAL $e t$ al., 2009; ANDERSON \& RAZA, 2010). Moreover, some of these studies reported that using very large areas for model calibration, especially if the species is absent from these areas, can result in serious ramifications for predictions and performance of ENMs (VANDERWAL et al., 2009; ANDERSON \& RAZA, 2010). We therefore

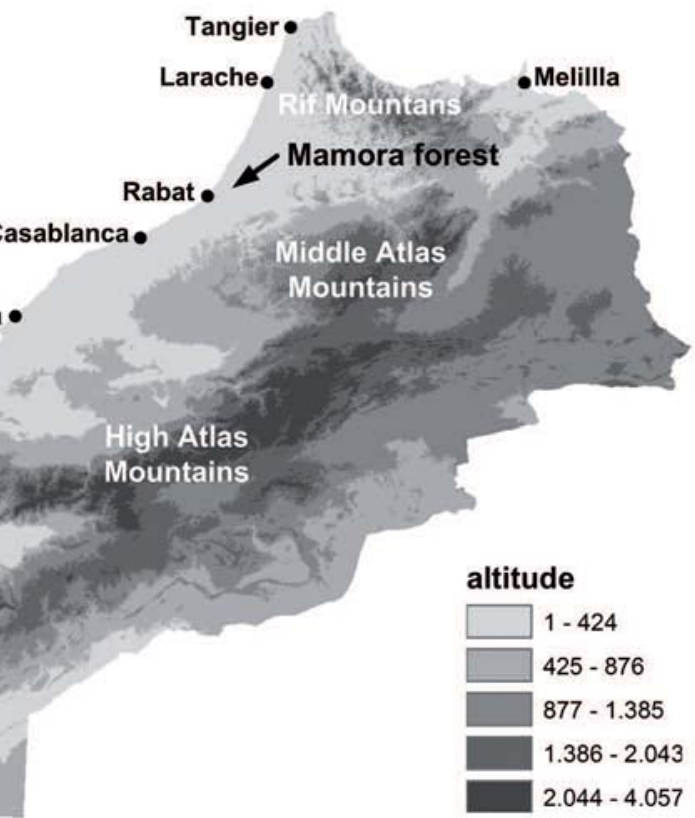


followed the background approach of WEBBER et al. (2011) and THOMPSON et al. (2011) and downloaded Köppen-Geiger polygons from the CliMond version 1.1 database (KRITICOS et al., 2012). Subsequently, models were projected onto a larger area (Fig. 1).

Models were created using three different combinations of environmental variables: (A) bioclimatic variables + NDVI + geology, (B) bioclimatic variables + NDVI, and (C) bioclimatic variables only. The average of ten pseudo-replicated models with randomly selected test samples was used to produce habitat suitability models, which were plotted in logistic format.

The final models were reclassified in ArcGIS 10 (ESRI, Redlands, California, USA) into binary presence-absence maps based on the lowest presence threshold (LPT). All models were tested with receiver operating characteristics (ROC) curve plots, which plot the truepositive rate against the false-positive rate. The average area under the curve (AUC) of the ROC plot of ten models was taken as a measu-

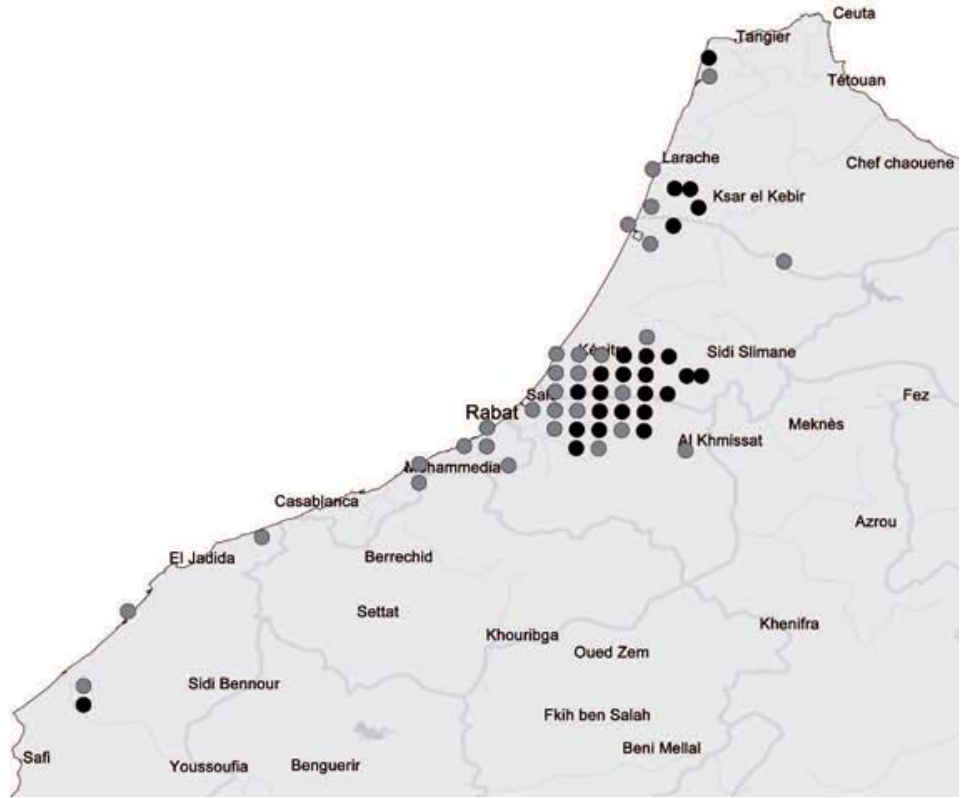

re of the overall fit of each model. Due to the fact that Maxent operates only with presence records, the AUC is calculated using pseudoabsences chosen at random from the study area (PHILLIPS et al., 2006). The AUC values range between 0.5 (highly unsuitable) and 1.0 (highly suitable) and display the probability that a randomly chosen presence site will be ranked above a randomly chosen absence site (PHILLIPS et al., 2006). Models with AUC values above 0.75 are considered useful (ELITH, 2002).

\section{RESULTS}

\section{Distribution and conservation status}

The distribution of $P$. varaldii can be divided into four main areas (Fig. 2): (1) The Mamora cork oak (Quercus suber) forest and surroundings, (2) the area around Larache, including the Loukkos basin and southwards along the road to Ksar-el-Kbir, as well as inside a royal hunting reserve northeast of

Figure 2: Distribution area of Pelobates varaldii in north-western Morocco with occupied UTM grids $(10 \times 10 \mathrm{~km})$ from literature (grey points) and current study (black points). 


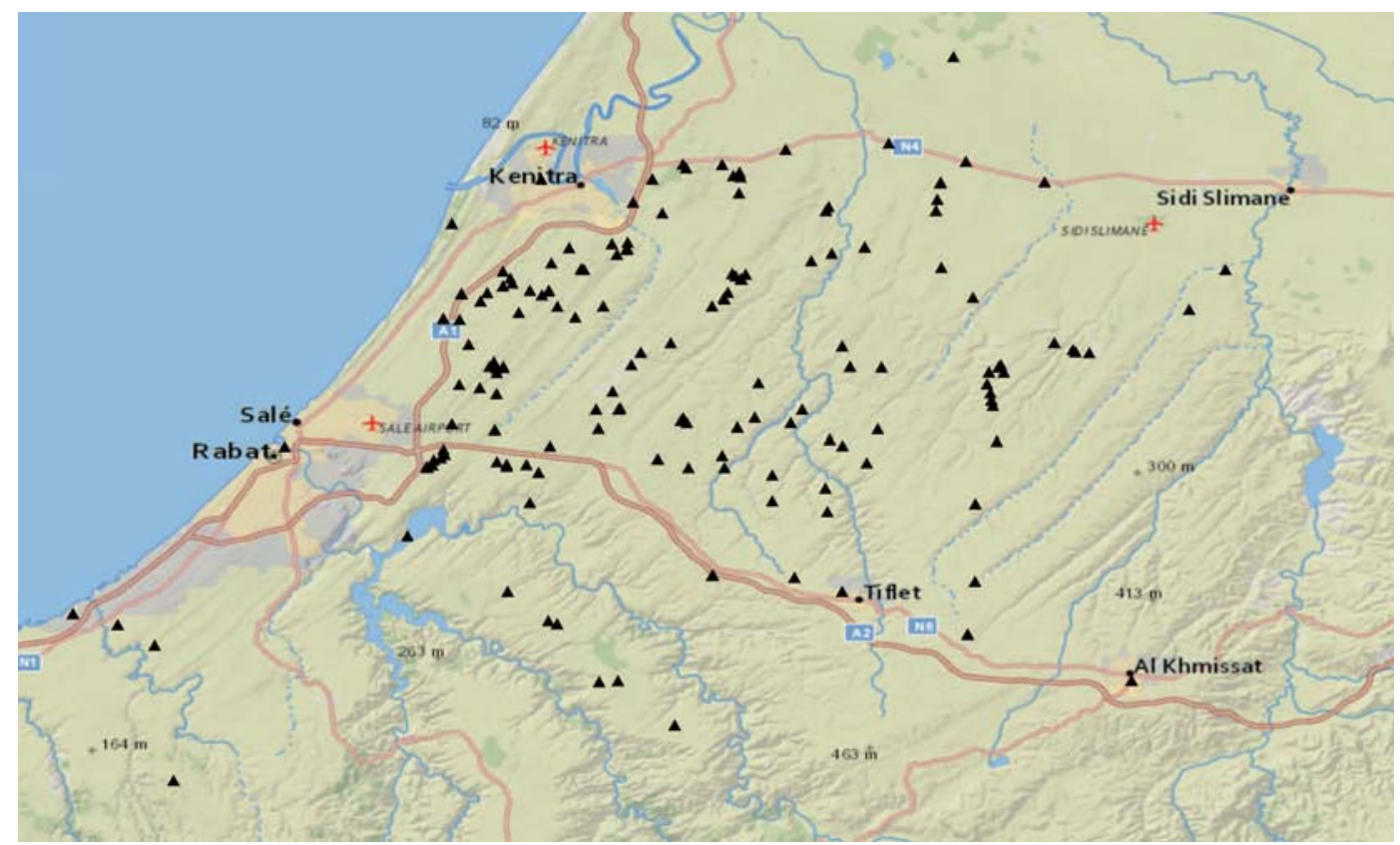

Figure 3: Detail of the distribution of Pelobates varaldii in the Mamora cork oak forest and surroundings (north-eastern Morocco). Black triangles indicate both newly discovered and literature records.

Moulay Bousselham, (3) the area between Asilah and Tangier, and (4) the Doukkala region between Rabat and Oualidia.

(1) During the 2008-2010 surveys in the Mamora cork oak forest more than one hundred and fifty temporary ponds distributed throughout the entire forest have been checked for presence of amphibian larvae. Pelobates varaldii larvae were detected in over $95 \%$ of the ponds, making it the most common amphibian species in the forest (Fig. 3). Many of the available breeding ponds (30\%) show human modifications such as deepening and ploughing, and surrounding habitats show high levels (55\%) of disturbance. Most of the ponds (> 80\%) show clear disturbance as a result of livestock pasturing.

(2) The 2008-2010 surveys detected and confirmed the presence of $P$. varaldii south of Larache on the way to Ksar-el-Kbir, approximately $20 \mathrm{~km}$ southeast of Larache, as well as in a Royal hunting reserve, between Moulay Bousselham and Ksar-el-Kbir. Threats in this part of the distribution are comparable to Mamora forest, but include: (i) the predation by $G$. holbrooki in some permanent water bodies where $P$. varaldii breeds; (ii) the recent (2007-2010) transformation of ponds into agricultural fields; and (iii) the discovery of the exotic crayfish species Procambarus (Ortmannicus) lophotus (J. Cooper, personal communication) in a P. varaldii breeding pond $\left(35.078269^{\circ}\right.$, $6.069084^{\circ}$ ) in 2007.

(3) A single locality south of Tangier airport was detected on 2 February 2009. The locality consists of a single breeding pond inside a Pinus pinea forest fragment and larvae density estimates in 2009 (catch per unit effort, CPUE) indicate a low population size. In January 2010, the 
Table 1: Response values percent contribution and permutation importance (in \%) of the climatic and categorical predictor variables for the ecological niche models of Pelobates varaldii from north-western Morocco (see text for the description of variables).

\begin{tabular}{ccccccc}
\hline \hline \multirow{2}{*}{ Variable } & \multicolumn{3}{c}{ Percent contribution } & \multicolumn{3}{c}{ Permutation importance } \\
& A & B & C & A & B & C \\
\hline Altitude & 38.9 & 41.9 & 47.4 & 24.5 & 33.6 & 10 \\
NDVI & 32.9 & 38.8 & - & 23 & 20.6 & - \\
Geology & 9.7 & - & - & 2.2 & - & - \\
BIO3 & 1.3 & 0.5 & 3 & 1.2 & 0.3 & 3.1 \\
BIO4 & 5.1 & 5.4 & 16.3 & 26.2 & 19 & 38 \\
BIO5 & 0.2 & 0.2 & 2 & 1.6 & 1.9 & 9.1 \\
BIO9 & 0 & 0 & 0.1 & 0 & 0 & 0 \\
BIO10 & 0 & 0.2 & 0.4 & 1.8 & 8.2 & 2.7 \\
BIO15 & 2.4 & 3.1 & 2.4 & 11.2 & 9 & 5.9 \\
BIO16 & 9.1 & 9.6 & 27.9 & 2.2 & 5.5 & 29.2 \\
BIO17 & 0.4 & 0.1 & 0.6 & 5.6 & 2 & 2 \\
\hline
\end{tabular}

locality was revisited and only very few, mostly malformed larvae could be caught.

(4) During the 2008-2010 surveys, no new populations could be detected in the region between Rabat and Oualidia, except for some populations just south of Mamora forest. Several expeditions into the Ben Slimane cork oak forest, with many temporary ponds present, did not result in a single observation of $P$. varaldii. In 2009, the Oualidia region was extensively surveyed for eight days, in which we searched for both tadpole presence and adults, but no specimens could be observed. On 16 February 2010, during rainy weather conditions, we confirmed the presence of the species in this region, with the finding of twelve individuals on the road, about 16 $\mathrm{km}$ west of Oualidia.

\section{Ecological niche modelling}

The final set of environmental predictor variables for the ENMs consisted of: altitude, isothermality (BIO3), temperature seasona- lity (BIO4), maximum temperature of the warmest month (BIO5), mean temperature of the driest quarter (BIO9), mean temperature of the warmest quarter (BIO10), precipitation seasonality (BIO15), precipitation of the wettest quarter (BIO16), precipitation of the driest quarter (BIO17), NDVI and superficial geology.

Maxent produced models of high predictive accuracy, according to the average test AUC of the three models $(A=0.969 \pm$ $0.013, \mathrm{~B}=0.973 \pm 0.015, \mathrm{C}=0.964 \pm$ 0.013 ). The main predictor variables (percent contribution and permutation importance) of $P$. varaldii can be found in Table 1. Visual interpretation of the response curves revealed that the probability of presence of the species decreases with increasing altitude, whereas it increases with higher precipitation of the wettest quarter. The species has a high probability of presence in eight NVDI classes (75 classes in the study area), all of which have a high year-round green biomass and occurs mainly on sandy Quaternary and karstic 


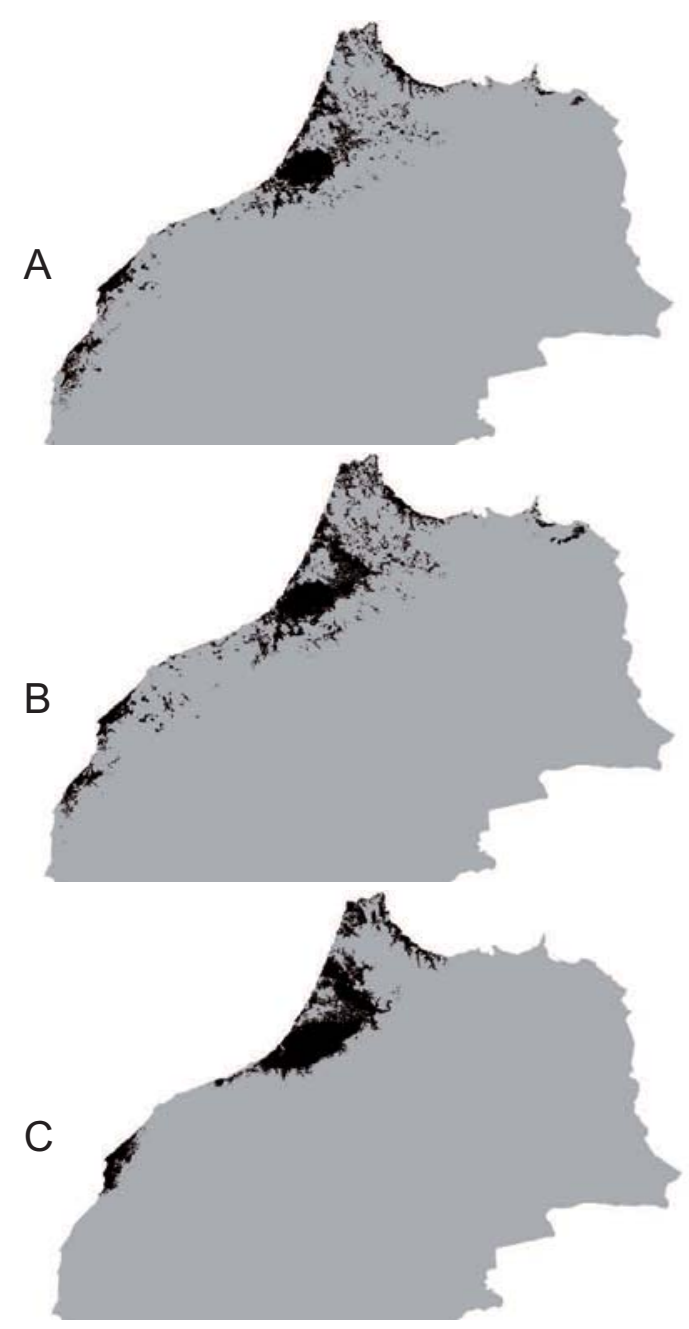

Figure 4: Habitat suitability maps (potential niche models) of Pelobates varaldii created using (A) climate variables + NDVI + geology, (B) climate variables + NDVI, and (C) climate variables only. Models are above the average lowest presence threshold.

Tertiary soil deposits (35 classes in the study region). The models of $P$. varaldii revealed a small and fragmented potential niche along parts of the northeast Moroccan coastline until Essaouira, as well as at some areas along the Mediterranean coast to the Algerian border except for model C (Fig. 4).

\section{DisCUSSION}

\section{Distribution and conservation status}

The Mamora forest forms the core distribution area of $P$. varaldii and harbours the largest populations. Despite that $P$. varaldii is still widely distributed throughout the forest, substantial habitat modifications such as overgrazing, logging, exotic tree plantations, transformation to agricultural land and industrial development are severely threatening the biodiversity of this unique habitat (e.g. CherKaOUI et al., 2009). The Mamora forest is highly fragmented (CHERKAOUI et al., 2009) and the original cork oak forest has shown a major decrease over the last centuries (HoOker \& Ball, 1878; Oliver, 1986; NafaA \& Watfeh, 2000). Populations of $P$. varaldii are now often confined to the direct surroundings of temporary ponds and populations are being fragmented due to unfavourable habitat and agricultural fields, leading to potential loss of gene flow and genetic variability. Gambusia holbrooki was only detected in permanent streams and water bodies. Since $P$. varaldii mostly breeds in temporary ponds, elimination through these predatory fishes therefore seems unlikely in the Mamora region.

The distribution between Mamora forest and the localities in the area around Larache is not well understood. The ENMs revealed substantial areas of suitable habitat in this region but fieldwork and literature did not confirm the presence of $P$. varaldii in this area. Literature records are limited to EL HAMOUMI \& Himmi (2010) who found P. varaldii in the Loukkos basin, and GUZMÁN et al. (2007) who recorded the species just south of Ouezzane. 
During our surveys we visited the latter area on two different occasions but we could not confirm the presence of $P$. varaldii in this area.

The newly discovered population south of Tangier airport is under severe threat by the development of a nearby beach resort and immediate actions in the form of habitat protection are needed to prevent this population from local extinction. The population seems to be confined to a single breeding pond in a small forest fragment and CPUE analysis indicates a low population size (unpublished data). The recent discovery of the species $6 \mathrm{~km}$ southwards of the Tangier airport locality (LAPENA et al., 2011) might indicate a wider distribution in this area and this requires further investigation.

The area between Rabat and Oualidia has been extensively explored by herpetologists during the past decades (BONS \& GenieZ, 1996). Despite this, very few records of $P$. varaldii from this region exist. The cork oak forest surrounding Ben Slimane harbours substantial amounts of original habitat and over 600 temporary ponds are present in this region covering a total surface area of 1994 ha (RHAZI et al., 2009). The multiple surveys into this area surprisingly did not produce any records of $P$. varaldii presence despite extensive dip netting of many temporary ponds. The presumed absence in this area is likely a result of unsuitable microhabitat and the lack of sandy areas was confirmed during surveys. The forest surrounding Ben Slimane is characterized by thick bushy undergrowth, and the additional presence of many small streams makes this area unsuitable for $P$. varaldii.

The distribution in the area between Rabat and Oualidia remains not well understood. Niche models indicate few suitable areas in this region and century long herpeto- logical explorations have produced very few sightings (BONS \& GENIEZ, 1996). Although most of these records came from bone remains in the rejection pellets of the barn owl (Tyto alba) and the African marsh owl (Asio capensis), this method can be considered a reliable prospection mode for $P$. varaldii because the radius of operation of $T$. alba rarely exceeds $4 \mathrm{~km}$ (Michelat \& Giraudoux, 1991). The Oualidia population is confined to a very small region of suitable habitat with several temporary ponds present. Despite extensive sampling of these ponds, no larvae could be detected in both 2009 and 2010. It remains unclear if the Oualidia population faces additional threats.

Yus Ramos \& Cabo Hernández (1986) reported the presence of $P$. cultripes near the Spanish enclave Melilla in north-eastern Morocco, but despite extensive herpetological exploration in this area, this occurrence was never confirmed. Several suitable areas are present in the region (Fig. 4) and therefore Pelobates sp. might indeed have inhabited the area. The origin of this possible and presumed extinct population remains unclear and can constitute both an introduction of $P$. cultripes from Spain, a relict population of $P$. varaldii following a range expansion during the glacial period or even a result of multiple colonization routes into Morocco from Spain. The area surrounding Melilla has seen major industrial development in recent years and the shrinkage of suitable lowland habitat as a consequence might have driven this population to local extinction. Another plausible scenario is that Yus Ramos \& CABO HeRnández (1986) misidentified other amphibians with P. cultripes, but due to the clear morphological differences this seems unlikely. 
Several currently identified threats have also been identified by previous authors (see introduction), whereas additional future threats to $P$. varaldii might be the recent arrival of the chytrid fungus (Batrachochytrium dendrobatidis) in Morocco (El Mouden et al., 2011), the reduction of gene flow and loss of genetic variability as a result of habitat fragmentation (e.g. DixO et al., 2009), the possible effects of climate change (DrioueCH et al., 2010) and the expansion of the recently detected invasive crayfish Procambarus (Ortmannicus) lophotus (e.g. CRUZ et al., 2006).

\section{Ecological niche modelling}

Century long herpetological explorations in most parts of Morocco, but especially the Tingitana Peninsula, Melilla region and central Atlantic coastal areas have never documented the presence of $P$. varaldii in these areas and therefore it is highly unlikely that these areas are inhabited by $P$. varaldii populations. TARKHNishVILI et al. (2009) found Pelobates syriacus presence significantly associated with integrative normalized difference vegetation index (INDVI). This result indicates the importance of vegetation cover productivity on the spatial distribution of Pelobates species and stresses the need to identify the distribution of suitable NDVI classes within the distribution of $P$. varaldii. As the NDVI values categorically increase towards that of the highest year-round green biomass and $P$. varaldii only occurs amongst the higher classes. This can be explained by the preference of the species for forested habitats. The associated NDVI classes partially match the known distribution (Fig. 4), but additionally extend eastwards into the Rif Mountains, parts of the Middle Atlas
Mountains and the region around Melilla. Suitable NDVI classes also occur in the Doukkala region, the area around Essaouira and Agadir, as well as in parts of the High Atlas. However, a major gap in suitable NDVI appears in the area between Casablanca and Oualidia (Fig. 4).

Many authors have shown that Pelobates species are dependant of arenaceous substrates (e.g. SCHLEICH et al., 1996; SCALI \& GENTILLI, 2003), which are mostly present along the Atlantic coastal plain in the northwest of Morocco. Despite that P. varaldii also occurs on other geology classes within the study region, most of these populations are restricted to the sandy microhabitat patches available. As an example, the area around Oualidia is characterized by saturated karsts (FAKIR et al., 2002) but small suitable sandy areas harbouring $P$. varaldii populations exist there.

Morocco is considered to be the foremost country in the Mediterranean basin for its richness in temporary ponds (GRILLAS et al., 2004). Despite the fact that these temporary ponds are distributed throughout the country, they show a remarkable diversity as a result of a range of climatic, geological and geomorphological conditions (GRILLAS et al., 2004). The coastal Atlantic plains are renowned for their high numbers of temporary ponds, which are characterized by soils that are either hydromorphic over a sandstone or schist substrate (Ben Slimane forest), or sandy over an impermeable clay layer (Mamora forest) (GRILlas et al., 2004). The larvae of Pelobates species have both the largest size and longest larval period known among anurans (BuChHOlz \& HAYES, 2002) and can reach lengths of $130 \mathrm{~mm}$ with larval periods that can last for over four months depending on condi- 
tions (e.g. SZÉKELY et al., 2010). The unique combination of geological and geomorphological conditions of the soil and the climate in the coastal Atlantic plain creates temporary ponds that have the ability to keep water levels for a period long enough to allow $P$. varaldii larvae for completing their larval development. Moreover, $P$. varaldii is known to inhabit direct surroundings of breeding waters and mainly breeds in temporary ponds (author's personal observation), therefore making the spatial distribution of suitable breeding waters a key indicator for identifying suitable habitat for the species. The temporary ponds of the type present in the coastal Atlantic plains stretch from around Tangier southwards to the area around Essaouira (GRILlas et al., 2004) and this corresponds to the potential niche models of P. varaldii (BONS \& GENIEZ, 1996).

\section{Conclusion and recommendations}

Overall, the ENMs seem to have performed well in predicting the distribution of P. varaldii. The Mamora forest forms the core distribution area and harbours the largest and healthiest population of $P$. varaldii, whereas several smaller and possibly fragmented populations exist in the area around Larache, Tangier, and Oualidia. The distribution between Rabat and Oualidia has still not been fully resolved but potential niche models and fieldwork indicates that this area mostly lacks suitable habitat. The largest threats to $P$. varaldii consist of a reduction of gene flow and loss of genetic variability as a result of habitat fragmentation, the transformation of habitat and breeding ponds into agricultural and industrial areas, the pollution of breeding ponds due to extensive livestock pasturing and the possible expansion of exotic crayfish species into the Mamora forest. Moreover, the report of $B$. dendrobatidis presence in Morocco and the infection of $P$. varaldii larvae near Larache (EL Mouden et al., 2011) could constitute a major future threat.

Proposed conservation actions include: (1) the development of a biannual monitoring program to assess the long term population status, (2) the identification of areas to be proposed as protected areas, and (3) the development of a management plan for Mamora forest to reduce negative effects of agriculture, logging and livestock on breeding ponds and habitat. Immediate conservation actions in the form of habitat protection are needed to protect the small population south of Tangier airport. It is highly recommended to monitor the status and expansion of exotic crayfish and to establish a program to extirpate this devastating invasive species.

\section{Acknowledgement}

This research was conducted in collaboration with the University of Applied Science Van Hall-Larenstein and the EDGE program (Zoological Society of London). M. Weterings, P-A. Crochet, J. Bosch and J. Cooper are thanked for their help and data sharing. DD and EHEM were partially supported by a 2004 DAPTF seed-grant. PdP was supported by a 2010 conservation grant of the Societas Europaea Herpetologica. Fieldwork in Morocco was conducted under permit decisions $84^{\circ} \mathrm{HCEFLCD/DLCDPN/}$ DPRN/CFF (2008-2009) and 10 HCEFLCD/ DLCDPN/DPRN/CFF (2010) issued by Haut Commissariat aux Eaux et Forêts et à la Lutte Contre la Désertification. 


\section{REFERENCES}

Anderson, R.P. \& RAZA, A. (2010). The effect of the extent of the study region on GIS models of species geographic distributions and estimates of niche evolution: preliminary tests with montane rodents (genus Nephelomys) in Venezuela. Journal of Biogeography 37: 1378-1393.

Beukema, W.; de Pous, P.; Donaire, D.; Escoriza, D.; Bogaerts, S.; TOXOPeus, A.G.; De BIE, C.A.J.M.; ROCA, J. \& Carranza, S. (2010). Biogeography and contemporary climatic differentiation among Moroccan Salamandra algira. Biological Journal of the Linnean Society 101: 626-641.

Bons, J. \& Geniez, P. (1996). Amphibiens et Reptiles du Maroc (Sahara Occidental Compris), Atlas Biogéographique. Asociación Herpetológica Española, Barcelona, Spain.

BuchHolz, D.R. \& HaYes, T.B. (2002). Evolutionary patterns of diversity in spadefoot toad metamorphosis (Anura: Pelobatidae). Copeia 2002: 180-189.

Busack, S.D.; MaXson, L.R. \& Wilson, M.A. (1985). Pelobates varaldii (Anura: Pelobatidae): a morphologically conservative species. Copeia 1985: 107-112.

Cherkaoui, I.; Selmi, S.; Boukhriss, J.; Hamid, R.-I. \& MoHAMmed, D. (2009). Factors affecting bird richness in a fragmented cork oak forest in Morocco. Acta Oecologica 35: 197-205.

Crochet, P.-A. \& Geniez, P. (2003). First live record of Pelobates varaldii Pasteur \& Bons, 1959 in the Oualidia area (Morocco). Herpetozoa 16: 93-94.

Cruz, M.J.; Rebelo, R. \& Crespo, E.G. (2006). Effects of an introduced crayfish,
Procambarus clarkii, on the distribution of south-western Iberian amphibians in their breeding habitats. Ecography 29: 329-338. de Pous, P.; Beukema, W.; Weterings, M.; DÜMMER, I. \& GENIEZ, P. (2011). Area prioritization and performance evaluation of the conservation area network for the Moroccan herpetofauna: a preliminary assessment. Biodiversity and Conservation 20: 89-118.

Destre, R.; Roux, P.; Geniez, P.; Thevenot, M. \& Bons, J. (1989). Nouvelles observations sur l'herpétofaune marocaine. Bulletin de la Société Herpétologique de France 51: 19-26.

Dixo, M.; MetZger, J.P.; Morgante, J.S. \& ZAMUdio, K.R. (2009). Habitat fragmentation reduces genetic diversity and connectivity among toad populations in the Brazilian Atlantic Coastal Forest. Biological Conservation 142: 1560-1569.

Dorda Dorda, J. (1984). Prospección herpetológica en el norte de Marruecos. Boletin Ghezoc 1: 19-28.

Driouech, F; Déqué, M. \& SÁnchezGÓMEZ, E. (2010). Weather regimes Moroccan precipitation link in a regional climate change simulation. Global and Planetary Change 72: 1-10.

El Hamoumi, R. \& Himmi, O. (2010). Distribution et état des lieux des peuplements d'Amphibiens dans le complexe de zones humides du bas Loukkos (Larache, Maroc). Bulletin de l'Institut Scientifique, Rabat, section Sciences de la Vie 32: 95-100.

El Mouden, E.H.; Slimani, T.; DonaiRe, D.; FERnÁNDEZ-BEASKOETXEA, S.; Fisher, M.C. \& BosCH, J. (2011). First record of the chytrid fungus Batrachochytrium dendrobatidis in North Africa. Herpetological Review 42: 71-75. 
ELITH, J. (2002). Quantitative methods for modeling species habitat: comparative performance and an application to Australian plants, In S. Ferson \& $\mathrm{M}$. Burgman (eds.) Quantitative Methods for Conservation Biology. Springer, New York, USA, pp. 39-58.

Elith, J.; Phillips, S.J.; Hastie, T.; Dudík, M.; Chee, Y.E. \& Yates, C.J. (2010). A statistical explanation of MaxEnt for ecologists. Diversity and Distributions 17: 43-57.

FAKIR, Y.; El Mernissi, M.; Kreuser, T. \& BERJAMI, B. (2002). Natural tracer approach to characterize groundwater in the coastal Sahel of Oualidia (Morocco). Environmental Geology 43: 197-202.

García-París, M.; Buchholz, D.R. \& Parra-Olea, G. (2003). Phylogenetic relationships of Pelobatoidea re-examined using mtDNA. Molecular Phylogenetics and Evolution 28: 12-23.

Giovanelli, J.G.R.; DE SiQUeIRA, M.F.; Haddad, C.F.B. \& AleXandrino, J. (2010). Modeling a spatially restricted distribution in the Neotropics: How the size of calibration area affects the performance of five presence-only methods. Ecological Modelling 221: 215-224.

Grillas, P.; GaUthiER, P.; YaVERCOVSKI, N. \& Perennou, C. (2004). Mediterranean Temporary Pools. Volume 1 - Issues Relating to Conservation, Functioning and Management. Station Biologique de la Tour du Valat, Arles, France.

Guzmán, J.L.; Ceacero, F. \& GarcíaMuñoz, E. (2007). Nuevas citas de anfibios y reptiles en Marruecos. Munibe S25: 82-87.

Hernandez, P.A.; Graham, C.H.; Master, L.L. \& AlBERT, D.L. (2006). The effect of sample size and species characteristics on performance of different species distribution modeling methods. Ecography 29: 773-785. Hijmans, R.J.; Cameron, S.; Parra, J.; Jones, P.; JARVIS, A. \& RiCHARDSON, K. (2005a). WorldClim - Global Climate Data, version 1.4. Available at http://www.worldclim.org/. Hijmans, R.J.; Cameron, S.E.; Parra, J.L.; Jones, P.G. \& Jarvis, A. (2005b). Very high resolution interpolated climate surfaces for global land areas. International Journal of Climatology 25: 1965-1978.

HOOKER, J.D. \& BALL, J. (1878). Journal of a Tour in Marocco and the Great Atlas. Macmillan and co., London, UK.

IsaAC, N.J.B.; Turvey, S.T.; Collen, B.; Waterman, C. \& Baillie J.E.M. (2007). Mammals on the EDGE: conservation priorities based on threat and phylogeny. PLOS ONE 2: e296.

JiméneZ-VAlVERde, A.; Lobo, J.M. \& Hortal, J. (2008). Not as good as they seem: the importance of concepts in species distribution modelling. Diversity and Distributions 14: 885-890.

Knutson, M.G.; Richardson, W.B.; ReineKe, D.M.; Gray, B.R.; Parmelee, J.R. \& WEICK, S.E. (2004). Agricultural ponds support amphibian populations. Ecological Applications 14: 669-684.

Krijgsman, W.; Hilgen, F.J.; RafFi, I.; Sierro, F.J. \& WiLSON, D.S. (1999). Chronology, causes and progression of the Messinian salinity crisis. Nature 400: 652-655.

Kriticos, D.J.; WebBer, B.L.; Leriche, A.; Ota, N.; Macadam, I.; Bathols, J. \& SCOTT, J.K. (2012). CliMond: Global Climatologies for Bioclimatic Modelling, version 1.1. Available at https://www.climond.org/. Retrieved on 01/31/2012. 
LAPEÑA, M.; BaRbadillo, L.J. \& MaRTÍNEZSolano, I. (2011). Geographic distribution. Pelobates varaldii. Herpetological Review 42: 108.

Michelat, D. \& Giraudoux, P. (1991). Dimension du domaine vital de la Chouette effraie (Tyto alba) pendant la nidification. Alauda 59: 137-142.

NAFAA, R. \& WATFEH, A. (2000). Holocene and actual degradation of the environment in the Mamora forest (Morocco). International Journal of Anthropology 15: 263-270.

Oliver, J.M.M. (1986). Model for a new sylvo-pastoral system in the Mamora cork-oak forest. Landscape and Urban Planning 13: 55-63.

Pasteur, G. \& Bons, J. (1959). Les Batraciens du Maroc. Travaux de l'Institut Scientifique Chérifien, Série Zoologie 17: 1-241.

Pearson, R.G.; RaXWorthy, C.J.; NakAMura, M. \& Peterson, A.T. (2007). Predicting species distributions from small numbers of occurrence records: a test case using cryptic geckos in Madagascar. Journal of Biogeography 34: 102-117.

Pellegrin, M.J. (1925). Les reptiles et batraciens du grand et du moyen atlas. Comptes Rendus Hebdomadaires des Séances de l'Académie des Sciences 181: 880-882.

Persits, F.; Ahlbrandt, T.; Tuttle, M.; Charpentier, R.; Brownfield, M. \& TAKAHASHI, K. (1997). Maps Showing Geology, Oil and Gas Fields and Geological Provinces of Africa. US Geological Survey, Open-File Report 97-470A, Denver, Colorado, USA.

Phillips, S.J.; Anderson, R.P. \& Schapire, R.E. (2006). Maximum entropy modeling of species geographic distributions. Ecological Modelling 190: 231-259.
PhiluIPS, S.J. \& Dudík, M. (2008). Modeling of species distributions with Maxent: new extensions and a comprehensive evaluation. Ecography 31: 161-175.

Pleguezuelos, J.M.; Brito, J.C.; Fahd, S.; Feriche, M.; Mateo, J.A.; MorenoRueda, G.; Reques, R. \& Santos, X. (2010). Setting conservation priorities for the Moroccan herpetofauna: the utility of regional red lists. Oryx 44: 501-508.

RHAZI, L.; GRILlas, P.; RHAZI, M. \& AZNAR, J.C. (2009). Ten-year dynamics of vegetation in a Mediterranean temporary pool in western Morocco. Hydrobiologia 634: 185-194.

Salvador, A.; Donaire-Barroso, D.; Slimani, T.; El Mouden, E.H. \& Geniez, P. (2004). Pelobates varaldii, In IUCN 2010. The IUCN Red List of Threatened Species. Version 2010.2. International Union for Nature Conservation and Natural Resources, Gland, Switzerland. Available at http://www.iucnredlist.org/. Retrieved on 10/01/2011.

SCALI, S. \& Gentilli, A. (2003). Biology aspects in a population of Pelobates fuscus insubricus Cornalia, 1873 (Anura: Pelobatidae). Herpetozoa 16: 51-60.

SChleich, H.H.; Kästle, W. \& KabisCh, K. (1996). Amphibians and Reptiles of North Africa. Koeltz Scientific Books, Koenigstein, Germany.

Shaffer, H.B.; Alford, R.A.; WoOdward, B.D.; Richards, S.J.; Altig，R.G. \& GASCON, C. (1994). Quantitative sampling of amphibian larvae, In W.R. Heyer, M.A. Donelly, R.W. McDiarmid, L.-A.C. Hayek \& M.S. Foster (eds) Measuring and Monitoring Biological Diversity. Standard Methods for Amphibians. Smithsonian Institution Press, Washington, D.C., USA, pp. 130-141. 
Székely, P.; Tudor, M. \& CogÃlniceAnu, D. (2010). Effect of habitat drying on the development of the Eastern spadefoot toad (Pelobates syriacus) tadpoles. Amphibia-Reptilia 31: 425-434.

TarkHNishVIll, D.; Serbinova, I. \& GaVashelishVILI, A. (2009). Modelling the range of Syrian spadefoot toad (Pelobates syriacus) with combination of GIS-based approaches. Amphibia-Reptilia 30: 401-412.

ThOMPSON, G.D.; ROBERTSON, M.P.; Webber, B.L.; Richardson, D.M.; Le Roux, J.J. \& Wilson, J.R.U. (2011). Predicting the subspecific identity of invasive species using distribution models: Acacia saligna as an example. Diversity and Distributions 17: 1001-1014.

VanDerWal, J.; Shoo, L.P.; Graham, C. \& Williams, S.E. (2009). Selecting pseudoabsence data for presence-only distribution modeling: How far should you stray from what you know? Ecological Modelling 220: 589-594. Veith, M.; Fromhage, L.; Kosuch, J. \& VenCES, M. (2006). Historical biogeography of Western Palaearctic pelobatid and pelodytid frogs: a molecular phylogenetic perspective. Contributions to Zoology 75: 109-120.
Verbruggen, H. (2012). OccurrenceThinner version 1.04. Available at http://www.phycoweb.net/software. Retrieved on 01/31/2012.

Warren, D.L.; Glor, R.E. \& Turelli, M. (2010). ENMTools: a toolbox for comparative studies of environmental niche models. Ecography 33: 607-611.

Webber, B.L.; Yates, C.J.; Le Maitre, D.C.; ScotT, J.K.; Kriticos, D.J.; Ota, N.; McNeill, A.; Le Roux, J.J. \& Midgley, G.F. (2011). Modelling horses for novel climate courses: insights from projecting potential distributions of native and alien Australian acacias with correlative and mechanistic models. Diversity and Distributions 17: 978-1000.

Wisz, M.S.; Hijmans, R.J.; Li, J.; Peterson, A.T.; Graham, C.H.; Guisan, A. \& NCEAS PREDiCTING SPeCIES Distributions WORKING GROUP. (2008). Effects of sample size on the performance of species distribution models. Diversity and Distributions 14: 763-773.

Yus Ramos, R. \& Cabo Hernández, J.M. (1986). Guía de la Naturaleza de la Región de Melilla. Excmo. Ayuntamiento de Melilla, Melilla, Spain. 